\title{
Differences in Marketing Communication Activities at Sheraton Surabaya Hotel $\&$ Towers in the middle of COVID-19 Pandemic
}

\author{
Jiwangga Hadi Nata a 1 iD, Nur Emma Suriani a ${ }^{\text {iD }, ~ M ~ R i z a ~ D a r m a w a n ~ a ~}{ }^{\text {iD }}$
}

${ }^{a}$ Universitas Airlangga, Surabaya, Indonesia

\begin{abstract}
APA Citation:
Nata, J.H., Suriani, N.E. \& Darmawan, M.R. (2020). Difference of marketing communication activities at Sheraton Surabaya Hotel \& Towers in the middle of a crisis due to the COVID-19 pandemic. TIJAB (The International Journal of Applied Business), 4(2), $125-138$.

Submission Date: 11/11/2020

Acceptance Date: 13/11/2020
\end{abstract}

\begin{abstract}
The tourism industry is a growing industry where hospitality is an essential business that provides accommodation for tourists. However, in early 2020 there was a COVID-19 pandemic that affected the crisis in the tourism industry. The decline in the number of tourists and the limited tourism activities lead to a decrease in consumer buying interest and here also the role of the marketing communication department as a department that promotes and is a liaison between hotels and consumers. The role of marketing communication in increasing the buying interest of prospective consumers is one of the factors that has an impact because of the activities of the department that exchange information with potential customers. This study aims to determine the promotion and adaptation activities carried out by the marketing communication of the Sheraton Surabaya Hotel \& Towers in facing a crisis due to the COVID-19 pandemic. In this study, researchers used qualitative methods where the data were analyzed first then arranged and explained with certain statements in the form of written or oral words from an informant and observing the place under study. The results of the study show that marketing communication department of the Sheraton Surabaya Hotel \& Towers is adapting to crisis management and using soft selling while planning steps to be taken after the crisis has passed. Marketing communication activities also help to maintain the buying interest of potential customers. The results also show that the use of promotion through social media is more flexible in various conditions.
\end{abstract}

Keywords: tourism, hotel, crisis, marketing communication, buying interest, covid-19

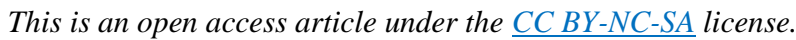

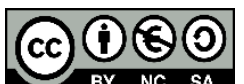

\section{Introduction}

Bank of Indonesia (BI) states that tourism is the most effective sector to boost Indonesia's foreign exchange. One of the reasons is because the resources needed to develop tourism are located in the country (Mikhael Gewat, 2020). Tourism being one of the largest sources of foreign exchange also

\footnotetext{
${ }^{1}$ Corresponding author.

E-mail address: jiwangga-hadi-nata@vokasi.unair.ac.id
} 
makes more sense because data on the number of foreign tourists showed a continuous increase over the last 5 years (2015-2019).



Table 1.1 number of foreign tourists visits in 2015-2020

Source: Indonesia's Central Bureau of Statistics in 2020

From the data above, it can be explained that the number of foreign tourists has continued to increase in the last 5 years (2015-2019). This indicates that tourism is one of the important industries, therefore its development needs to be paid attention considering that Indonesia has supporting resources. The supporting resources refer to various tourist destinations, cultural wealth, and other factors that Indonesia possesses to support the development of the tourism industry itself.

The size of the tourism industry is accompanied by the rate of development must also be accompanied by supporting factors in order to carry out good and comfortable tourism activities. Accommodation has an essential role in supporting tourism activities. In this case, the accommodation is the hospitality as an important supporting factor in tourism industry. Surabaya as one of the biggest cities in Indonesia has a lot of hotels in town. Because of the large number of hotels in Surabaya, each hotel must have its own strategy in promoting every product that it has.

However, in 2020, the world experiences the COVID-19 Pandemic, which is a virus that can cause disease in animals or humans and COVID-19 is an infectious disease caused by a newly discovered type of coronavirus. This pandemic will definitely have an impact on the tourism industry in the world, including in Indonesia. Based on the nature of this disease, many countries in the world implement social 
restrictions and urge people to avoid crowds and also cancel their travel activities in countries affected by this pandemic which also limits tourism activities.



Table of foreign tourist visit decrease in March 2020

Source: Indonesia's Central Bureau of Statistics in 2020

Due to the condition that has been occurring, many hotels are experiencing a crisis due to the COVID19 pandemic which has caused a drastic drop in the number of tourist visits. Therefore, every company must adapt to all existing conditions, including the crisis due to the ongoing COVID-19 Pandemic. Among activities that a hotel must adjust, one of the important activities is the change in the activities of the marketing communication department.

The adaptation of the marketing communication department activities becomes one of the things that must be paid attention considering the exchange of information between companies and external companies is carried out through the marketing communication department, therefore, its activities must be performed carefully and planned completely.

As a department that connects companies and consumers, the marketing department is one of the most important things that must be considered when companies face any crisis including crises because the COVID-19 pandemic considering that one of the responsibilities of the marketing communication department at Sheraton Surabaya Hotel \& Towers is crisis management. In addition to crisis management, the activities of the marketing communication department as a department that promotes hotel products to help maintain consumer buying interest in the midst of the COVID-19 pandemic.

The differences in activities carried out by the marketing communication department need to be discussed because of the different handling, difficult challenges and also the unprecedented pandemic conditions. The authors find it interesting to discuss, because if the company takes a wrong step, it will have a huge impact on the company.

Based on the understanding on the relationship among the marketing communication department, the differences in the marketing communication department activities, consumer buying interest, and the impact of the COVID-19 pandemic, the authors consider that it is important to discuss a topic entitled "Differences in Marketing Communication Activities at Sheraton Hotel \& Towers Surabaya in the middle of a crisis due to the Covid-19 pandemic". In addition, based on the existing background, the authors raise several problems, namely 1 ) how is the marketing communication activity of Sheraton 
Hotel \& Towers Surabaya? and, 2) how is the marketing communication activities of Sheraton Hotel \& Towers Surabaya in the middle of a crisis due to the COVID-19 pandemic? It also aims to 1) find out how the marketing communication activities of Sheraton Surabaya Hotel \& Towers and, 2) to find out the differences in the marketing communication activities carried out by Sheraton Surabaya Hotel \& Towers in the middle of a crisis due to the COVID-19 Pandemic.

\section{Literature Review}

\subsection{Marketing communication}

According to Bambang (2018: 11), marketing communication is carried out to disseminate information (informative communication); second, to influence someone or anyone to make a purchase or to attract consumers (persuasive communication); and third, to remind the audience to make repeat purchases (recall communication). In marketing communication, the meaning of each promotion tool according to Widyastuti (2017:22-23) is as follows:

1. Advertising; every paid for from non-personal presentations and promotion of ideas, goods, or services by identified sponsors through printed media, broadcasted media, network media, electronic media.

2. Online and Social Media Marketing; online activities and programs designed to engage customers or prospects directly or indirectly to raise awareness, enhance image, or generate sales of products and services. Mobile Marketing (marketing with movements); a special form of online marketing that locates communication on a consumer mobile phone, smartphone, or tablet.

3. Sales Promotion; sales promotion is all kinds of activities designed to increase short-term sales. Various short-term incentives to encourage the trial or purchase of a product or service include customer promotions (such as samples, coupons, and premiums), trade promotions (such as advertising and benefit displays), and business and sales force promotions (contests for sale reps).

4. Personal Selling (Direct Marketing) or direct selling is the activity of selling products face-to-face with one or more prospective employees for the purpose of making presentations, answering questions, and procuring orders. It can be done through telemarketing, or the internet to specific or certain target consumers.

5. Events and Experiences are activities and programs designed to make corporate sponsored or specific communication related to brand interactions with consumers, including sports, arts, entertainment, and less formal events and activities.

6. Direct Marketing and Database. It uses mail, telephone, fax e-mail, or internet to communicate directly with or request feedback or dialogue from specific customers and prospects.

According to Bambang (2018: 11-12), marketing communication are carried out to disseminate information. Therefore, good marketing communication will have an effect on three important aspects, namely:

1. Cognitive effect: forming awareness of certain information,

2. Affective effect: giving the effect of doing something. What is expected is a purchase reaction,

3. Conative or behavioral effect: forming audience patterns into subsequent behaviors. The expected behavior is re-purchase. From the three aspects above, they will affect consumer buying behavior. 


\subsection{E-Marketing}

E-marketing can be defined as an integrated process which is a company effort to send marketing messages to target segments using the internet and other digital-based marketing tools where emarketing can be applied in traditional communication tools (sales promotion, advertising, communication with the public) by implementing online elements which are also used to identify the company's target market, understand online consumer behavior, form opinions about company brands, and increase online brand awareness (Labanauskaite et al., 2020:3). Company selection in determining the form of online interactive marketing and promotion will save more costs. According to Bambang (2018: 25), there are several interactive forms of marketing on the internet:

\section{Website}

Company needs to use the website as a medium to express its goals, history, products, mission and vision. The main challenge in designing a website is to make an attractive appearance to encourage repeat visits from consumers, pay attention to content and display composition, and a user experience that is easy to understand and use.

\section{Microsite}

Microsite is an individual web that functions as a link to the main site. It will be especially useful for companies selling less desirable products.

\section{Search Ads}

The term of search functions to connect to relevant links to offer products or services. The search is done through search engines (Google, MSN, Yahoo, and others)

\section{Display Ads}

A display ad or banner ad is a small rectangular box containing text and images that companies pay to place relevant web sites in the box. Thus, if there is a well-known website of a person or company, Display Ads can be put. On the web, visitors are allowed to visit the Display Ads provided.

\section{Interstitial Ads}

It has the form of video and animation that appears between changes to a website. As some consumers feel that pop-ups are annoying, many users of devices such as AOL software are installed to block these pop-up ads.

\section{Internet-specific Ads and Videos}

With user-generated content sites such as YouTube, MySpace Video and Google Video, consumers and advertisers can upload advertisements and videos for millions to share.

\section{Sponsorship}

More companies promote their name on the internet by sponsoring special content on websites that carry news, financial information and so forth. Sponsors are best placed in targeted locations that provide relevant information or services. I-bayar sponsorship is to display the content of the image as a sponsor of a special service on the site.

\section{Alliance}

When an internet based company cooperates with other companies, they will carry out alliances and affiliate programs

\section{Online Community}


Many companies sponsor online communities in which their members communicate through posting, instant messaging, and discussions on personal interests related to company products and brands. With this community, comments are considered more valuable.

10. E-mail

By using email, a person can make significant savings when compared to using d'mail or direct mail.

\section{Mobile Marketing}

With its mobile nature, it offers marketers to personalize messages based on demographics, so that the appeal of online marketing can be clear.

\subsection{Crisis}

Crisis is an uncommon situation that presents several major risks to the business, which are described as follows:

1. A major failure in company systems, a serious accident or a dangerous incident creates a hazard and threat to people, property or the environment

2. Sudden and unforeseen events involving massive damage and loss of control that require immediate action to restore safe and efficient operations

3. Something that could seriously affect the company's image, affect its earnings and undermine its commitment to social responsibility and its right to operate (Shaluf et al., 2001).

Binus University Malang (2017) states when a crisis occurs, it is the stakeholder who perceives the greatest impact. Therefore, management must provide statements and actions that show concern and seriousness about the ongoing crisis as well as crisis management that must be done. Crisis management has management stages, namely:

1. Before the Crisis is the initial stage where the crisis has not yet occurred, but preparations need to be made so that the company is ready to face a crisis when one day it will occur

2. During the Crisis is the stage that occurs when a crisis has occurred and begins to involve parties to overcome the crisis that is befalling the company.

3.After the crisis is the last stage when a crisis occurs. In this stage, management evaluates the strategy for handling the crisis, whether it has a significant impact or it needs improvement.

\subsection{COVID-19}

COVID-19 is a new disease, different from other diseases caused by coronavirus, such as SARS and MERS. The virus spreads rapidly, and outbreaks can grow at an exponential rate. At present, there are no proven therapies or vaccines to treat or prevent COVID-19, although national governments, WHO, and partners are working urgently to coordinate the rapid development of medical precautions. According to data from the countries affected early in the pandemic, about $40 \%$ of cases will develop mild disease, $40 \%$ will develop moderate disease including pneumonia, $15 \%$ of cases will develop severe disease, and $5 \%$ of cases will have critical illness.

\subsection{COVID-19 travel advice}

It is preferable for sick travellers to delay or avoid traveling to affected areas, in particular for elderly tourists and people with chronic illnesses or underlying health conditions. Recommendations for maintaining personal hygiene, cough etiquette and maintaining a distance of at least one meter from people showing symptoms are still tremendously important to all travellers. This includes: 
1. Keep frequent hand hygiene, especially after contact with respiratory secretions. Hand hygiene includes cleaning hands with soap and water or with an alcohol-based hand rub. Alcohol-based antiseptics are preferred if hands are not visibly dirty; wash hands with soap and water if they look dirty.

2. Cover nose and mouth with bent elbows or a tissue when coughing or sneezing and throw away the tissue and wash hands immediately afterward.

3. Do not touch the mouth and nose.

4. Medical masks are unnecessary if no symptoms is shown, as there is no evidence that wearing any kinds of masks protects people who are not sick. However, in some circumstances, masks may be used. If a mask is to be worn, it is extremely important to follow the instructions for wearing, removing, and disposing of it followed by hand washing to make sure it is clean.

Travelers arriving from affected areas should observe symptoms themselves for 14 days and follow the national protocols of the receiving country. Some countries may require returning travellers to do quarantine. If symptoms occur, such as fever, cough or difficulty in breathing, travellers are advised to contact their local health care provider, preferably by phone and inform them of their condition and history.

\subsection{Consumer behavior}

According to Mihaela (2015) there are five values in terms of decision alternatives that can influence consumer behavior:

1. Functional Value, from product attributes or characteristics such as durability, price, and others.

2. Social Value, consumers have certain thoughts about purchasing products based on associations with demographic variables: age, sex, religion; socioeconomic: income level, occupation, etc.; culture: race, religion; political

3. Emotional Value, an alternative to obtain emotional value when associated with certain feelings.

4. Epistemic value, alternative decision obtains epistemic value through things such as curiosity, novelty, and desire for knowledge. The epistemic aspect relates to the reasons that justify the perceived satisfaction through curiosity, desire for knowledge, and exploration of the needs offered by the product.

5. Conditional Value, a decision alternative obtains a conditional value as a result of physical and past experiences.

As consumers, before buying something as a final decision, we will definitely be influenced by certain factors. According to (Brennan et al., 2008), there are several factors, namely:

\section{Culture}

Culture is the most basic determinant of a person's wants. Growing up children acquire a set of values; perceptions, preferences and behavior through a socialization process involving family and other major factors. Cultural factor has a significant effect on consumer behavior. Cultural shift affecting the product forces the marketing of a company to recognize products that consumers may want.

\section{Social}

Consumer buying behavior is also influenced by social factors, such as the group where the customer is in social status. Within a group, several individuals can interact to influence purchasing decisions. A distinctive role in such group decisions can be accompanied by the following: a) influence: a person whose views or advices influence the purchase decision, b) Determinant: a person with the power and financial authority to make the final decision about which product to buy, c) Buyer: a person who makes transaction, d) User: a person who actually uses the product or service. 


\section{Personal}

Personal factor is the factor that is unique to a particular person such as: demographic factor, sex, race, and age. Personal factor also includes who in the family is responsible for decision making.

4.Psychological Factor

Psychological factors include: a) motive, b) perception, c) ability and knowledge, d) attitude, e) personality, f) lifestyle, g) opinion leaders, h) family roles and influences, i) group references, j) social class, k) culture and sub-culture.

Mihaela (2015) states that in today's competitive environment, organizations must continue to communicate with potential and current interests, provide quality products and services, set attractive prices and facilitate their access to consumers. Therefore, marketing communication is the focus of all these activities given that consumers' perceptions and attitudes towards certain products and services can be influenced through communication messages sent, which have the role of convincing consumers to buy products and services.

According to Xliema (2019) Customers who have a good impression of the company will recommend it to others and large interactions usually occur on social networks as online reviews which then have a big effect on consumer buying behavior. Isa et al. (2016) declares that online social interaction is divided into two namely:

1. Opinion-based social interaction, usually known as online reviews, refers to the positive or negative opinions of online consumers on products and sellers

2. Habit-based social interaction that is fixated on observational learning, consumers make purchasing decisions from observing the buying actions of other people.

From the relations mentioned above, the interactions that occur and the good impression of consumers on a product or company will have an effect on buying interest which increases the interest of other consumers to visit because of the influence of social interaction on a product.

\section{Method}

The research was conducted at Sheraton Surabaya Hotel \& Towers, which is a 5-star hotel located in the center of Surabaya. It is at Embong Malang Street No. 25-31 Surabaya with telephone number 0315468000. Sheraton Surabaya Hotel \& Towers is right next to the biggest mall in Surabaya, namely Tunjungan Plaza. Not only adjacent to Tunjungan Plaza, but it also has direct access that connects the Sheraton Surabaya Hotel \& Towers with Tunjungan Plaza. Apart from Tunjungan Plaza, Sheraton Surabaya Hotel \& Towers is also close to other shopping centers such as BG Junction which can be reached by a five-minute drive, Grand City and Plaza Surabaya which can be reached by a 15-minute drive. The hotel is also close to one of the historical tours in Surabaya, namely, the Submarine Monument, which can be reached in 15 minutes. Having a strategic location makes this hotel easy to reach. It is only aabout 50 minutes from Juanda Airport, 30 minutes from Surabaya Gubeng Station. Consisting of 28 floors, this hotel has an interesting view of the city of Surabaya.

The authors chose the Sheraton Surabaya Hotel \& Towers as the location used for research because the authors assumed that it would be more in control because the authors carried out the Fieldwork Practice at the Sheraton Surabaya Hotel \& Towers and the authors also have interest in Marriott.

The data collection was carried out by the authors through: 1) Observation \& participation. Observation is an activity carried out to find out something from a phenomenon based on knowledge and ideas that aims to obtain information related to a phenomenon or event that has occurred or is happening in the environment. The authors also make direct observations at the Sheraton Surabaya Hotel $\&$ Towers and are directly involved in the way of working as a marketing communication at the Sheraton 
Surabaya Hotel \& Towers, 2) interview is a data collection which is a process of verbal and direct question and answer from the informants. Authors conducted structured interviews, namely interviews where a set of predetermined questions prepared by the previous interviewer and on this occasion, the authors performed an interview with the manager of marketing communication complex and marketing communication coordinator who can provide the required information related to the study. The marketing communication manager also provided a lot of information for the authors during the authors' attendance on the job training at the Sheraton Surabaya Hotel \& Towers, 3) literature study, the authors collected data and information by studying reference books, reports, journals, articles, theses, and other media related to the study, 4) documentation, is a form of record of past events (documents used by authors here are in the form of photos, pictures, and data about the Sheraton Surabaya Hotel \& Towers) and, 4) a questionnaire where the authors distributed a questionnaire to prospective respondents over 20 years old in which according to the authors, the hotel products has become one of the choices for the needs of prospective respondents and also prospective respondents were old enough to be able to influence the surrounding people to a hotel product. The distributed questionnaire also contains questions to collect data and is also a supporting factor for the information that has been given in this study.

Data collection was divided into several parts, starting from the implementation of the Fieldwork Practice on January 6, 2020 to July 6, 2020, then the preparation of the final project report which was carried out in February-May 2020 and was collected at the end of May 2020 and the last stage was the implementation of the examination which was held on 09 June 2020.

\section{Results and Discussions}

4.1. Activities of Sheraton Surabaya Hotel \& towers marketing communication in the middle of a crisis due to the Covid-19 pandemic

In the management of hotel activities, especially at the Sheraton Surabaya Hotel \& Towers, there are several activities carried out by the marketing communication department. The activities carried out also have various purposes, the main thing is definitely providing information to customers about the types of hotel services and products offered. Besides providing information to customers, the marketing communication department is also responsible for carrying out its duties as one of the hotel equipment. This is in accordance with the results of an interview with Geraldina Kumala as Marketing Communication Coordinator of Sheraton Surabaya Hotel \& Towers that marketing communication activities consist of: 1) Media Monitoring, 2) Promotion (including content creation to publication), 3) Maintaining Social Media (Instagram, Facebook ), 4) Digital Marketing, 5) Media Relations, 6) Crisis Management, 7) Event Coordinator, 8) Conducting CSR (interview result on May 19, 2020). It was then complemented by Birgitta Monne as Marketing Communication Manager Complex at Sheraton Surabaya Hotel \& Towers that marketing communication activities include: 1) Implementing the Sheraton brand voice, 2) Maintaining good relations with stakeholders (media, guests, clients, owners, communities) with several activities such as media visits, dine experiences with local foodies/Instagram celebrities/ influencers and, 3) CSR (Company Social Responsibility) (interview results on May 20, 2020).

One of the activities of the marketing communication department that has an important role is managing social media. This is in accordance with the results of an interview with Geraldina Kumala as Marketing Communication Coordinator of the Sheraton Surabaya Hotel \& Towers: With promotion, we publish what we sell to prospective consumers, the more exposed they are, the higher the buying interest. With social media, it will create closeness between us and consumers, so that consumers can better understand the latest updates from the hotel and consumers will find it easier to contact the hotel. All 
this closeness will increase buying interest. By holding an event in a certain promo, consumers will be more interested because they get an activity that is useful for them besides buying products (interview result on May 19, 2020).

\subsubsection{Activities of Sheraton Surabaya Hotel \& towers marketing communication in the middle of a crisis due to the Covid-19 pandemic}

Here, the Sheraton Surabaya Hotel \& Towers does not assert that changes in activity are only during the COVID-19 pandemic, but the company must adapt to whatever crisis conditions affect the company, so this is a fundamental adaptation process when the company experiences a crisis. The marketing communication department's adapting activity is crisis management which is also one of the responsibilities of the marketing communication department of Sheraton Surabaya Hotel \& Towers. When a condition affects the performance and operation of a hotel significantly, that is where the company must carry out crisis management in order to avoid risks and keep everything under control. The COVID-19 pandemic that is occurring at the time this study was written also has an effect to the Sheraton Surabaya Hotel \& Towers where the company has to adapt to existing conditions, including the marketing communication department. Birgitta Monne as Marketing Communication Manager Complex for Sheraton Surabaya Hotel \& Towers stated that the steps for crisis management in the marketing communication department are: Knowing that the crisis is ongoing - studying from various points of view about what and why the crisis is taking place - communicating intensively with the PR team from the head office - preparing a press release that has been approved by the PR Head Office if needed - preparing spoke person from the Management for all questions from the media if needed (interview result on May 20,2020). In facing the crisis by the company, absolutely, there are differences in marketing communication activities. Birgitta Monne as Marketing Communication Manager of the Sheraton Surabaya Hotel \& Towers Complex stated that adapting an effective communication system to the community, preparing communication channels if needed as an example of management responses to the ongoing crisis (interview results on May 20,2020). This explanation is one of the activities that changes due to company conditions. The company carries out crisis management not only to adapt and work on what is happening but also what will happen, therefore, the company must be really careful in taking steps. Birgitta Monne as Marketing Communication Manager Complex for Sheraton Surabaya Hotel \& Towers asserted: when the crisis is still ongoing, we will focus on preparing activities that will be carried out after the crisis has passed, not when the crisis still occurs. During a crisis, people's purchasing power may decrease. We also have to be careful in conveying the message that so as not to become a boomerang to the company in the future (interview results on May 20, 2020).

Apart from crisis management, corporate promotional activities have also been affected due to the crisis caused by COVID-19. In facing such conditions, there are promotional media that cannot be used because it contradicts the government's appeal that calls for social and physical distancing in the midst of the COVID-19 Pandemic. Therefore, the company also adapts to these conditions. Birgitta Monne as Marketing Communication Manager Complex for Sheraton Surabaya Hotel \& Towers declared that Sheraton used the following media to carry out promotions even before the COVID-19 Pandemic: 1) Conventional media - TV, radio, newspapers, 2) New media - social media, media online (interview results on May 20,2020). Then she also added that there were differences in the promotional activities carried out: when the crisis took place, we did not carry out hard selling promotion, we did more soft selling and formulated plans after the crisis had passed (interview results on May 20, 2020). From all the marketing communication activities carried out by Sheraton Surabaya Hotel \& Towers in the midst of a crisis due to the COVID-19 pandemic, it must have the goal of every step taken, one of which is to maintain the buying interest of consumers who are certainly affected by the existing conditions; thus, there are many factors that influence consumers to make purchase decisions, including the conditions 
experienced. The company also always strives to offer products that are suitable so that consumer purchases are realized. Birgitta Monne as Marketing Communication Manager Complex for Sheraton Surabaya Hotel \& Towers stated that: Marcomm activity is not the main indicator in increasing consumer purchasing power, because consumer purchasing power is determined by many things, including: product, price, location, competitor activity. Hence, the indicator of the success of Marcomm's activities lies in how stakeholders trust the brand. It is how people can believe that the Sheraton is the best 5-star hotel, for example, or how Kafe Bromo or Lime Restaurant can be trusted as the best hotel restaurant (interview results on May 20, 2020).

Consumer trust is also an important factor in decisions before consumers make a purchase, therefore, it is important for companies to gain that trust. However, this is not the responsibility of one department only to gain consumer trust but all hotel departments that work together to perform excellent service. Because it should be in the hotel industry involving many departments to run it. The marketing communication department is no exception to the efforts that have been listed above. Birgitta Monne as Marketing Communication Manager Complex for Sheraton Surabaya Hotel \& Towers also stated that: Consumer trust is not only obtained from the efforts of the Marcomm, but also the continuous efforts of all departments. Marcomm is only assigned with disseminating and educating the public about hotel, but to maintain consumer trust, definitely other parties must also participate in this (interview results on May 20, 2020).

On this occasion, the authors also distributed online questionnaires to people over 20 years old who usually already need hotel products, are able to buy hotel products, and also have the possibility of influencing other people to buy hotel products. The questionnaire received 36 respondents and resulted in the following answers: 1) Have you ever seen hotel product offers (rooms, food, or other offers) on social media or newspapers? It obtained result of $94.4 \%$ stating that they have and $5.6 \%$ have never seen it, 2) In the midst of the COVID-19 pandemic, what media do you use if you want to find information about hotel products? It obtained results that $50 \%$ chose Instagram, $25 \%$ web, $8.3 \%$ contacted the hotel phone number, $8.4 \%$ used the Traveloka application, $5.6 \%$ used other online travel booking applications, and $2.7 \%$ came directly to the hotel, 3) What do you think which affects your buying interest and that of others in buying hotel products in the midst of the COVID-19 pandemic? It obtained results that $58.3 \%$ answered attractive promos and $41.7 \%$ needs, 4) Does hotel product promos on social media (Instagram, Facebook, or other digital platforms) make it easier and increase your buying interest in the midst of the COVID-19 pandemic? It obtained results that $80.6 \%$ of respondents answered 'Yes', and $19.4 \%$ answered 'No', 5) Does active social media help you before buying a product (hotel product or other product)? $94.4 \%$ of respondents agree that active social help before they buy a product, but $5.6 \%$ stated that it has no effect, 6) Does an interesting product photo help to increase your buying interest as a consumer to buy a product? (any product). The authors obtained results that $94.4 \%$ answered 'Yes' and $5.6 \%$ answered 'No'.

From the results of the questionnaire obtained by the authors, it can be concluded that: 1) respondents are more likely to use social media in seeking information, 2) purchase interest of potential customers can be supported by other factors that can be pursued by the hotel or company. The questions above are part of the questionnaire results obtained by the authors.

\section{Conclusions}

Based on the results of the research that has been done, the authors make some conclusions. First, the difference in activities carried out by the marketing communication department of Sheraton Surabaya Hotel \& Towers when the company is experiencing a crisis is conducting crisis management by focusing on activities that will be carried out after the crisis has passed. 
Second, apart from crisis management, different activities carried out by the marketing communication department of the Sheraton Surabaya Hotel \& Towers are also carried out on promotional activities that are focused on soft selling and not hard selling. It is the right choice because it is seen from the results of the questionnaire that most respondents choose social media to find information about a product.

Third, digital marketing is a flexible marketing method proven by its easy use and fast information exchange which makes this marketing method suitable for various company conditions.

Additionally, the results of the questionnaire also reveal that most respondents use social media as a tool to help finding information. This is directly proportional to the soft selling chosen by Sheraton Surabaya Hotel \& Towers where the media is the most suitable for crisis conditions caused by the COVID-19 pandemic. The activities of the marketing communication department are one of the keys to optimal cooperation among departments at the Sheraton Surabaya Hotel \& Towers as written in the previous chapter that promotional activities are information exchange activities from companies to consumers; therefore, they must be carried out completely and planned. Crisis management is something that must be considered by a company because the company must be able to adapt to conditions that can change at any time.

\section{References}

Andrean, Sampir. (2018). "New Komunikasi Pemasaran: Teori dan Aplikasinya". Jember: Pustaka Abadi

Anggi. (2020). "Kunjungan Wisman Pada Maret 2020 Turun 64,11 Persen", https://www.suarasurabaya.net/kelanakota/2020/kunjungan-wisman-pada-maret-2020-turun6411-persen/ (accessed on 04 May, 2020)

Badan

Pusat

Statistik.

(2016).

https://www.bps.go.id/pressrelease.html?katsubjek=\&Brs\%5Btgl_rilis_ind $\% 5 \mathrm{D}=01 \& \mathrm{Brs} \% 5 \mathrm{Btah}$ un\%5D=2020\&yt0=Cari (accessed on 05 April 2020)

Badan Pusat Statistik. (2020). https://jatim.bps.go.id/statictable/2017/10/17/681/hotel-dan-kamarmenurut-klasifikasi-hotel-di-provinsi-jawa-timur-2016.html (accessed on 05 April 2020)

Badan Pusat Statistik. (2020). https://www.bps.go.id/pressrelease/2020/05/04/1714/jumlah-kunjunganwisman-ke-indonesia-maret-2020-mencapai-470-90-ribu-kunjungan-.html (accessed on 18 May 2020)

Binus University Malang. (2017). "Tahapan Penglolaan Krisis Manajemen". https://binus.ac.id/malang/2017/09/tahapan-pengelolaan-krisis-manajemen/ (accessed on 18 May 2020)

Brennan, R., Baines, P., Garneau, P., Vos, L., Brennan, R., Baines, P., Garneau, P., \& Vos, L. (2008). Understanding Consumer Behaviour. Contemporary Strategic Marketing, 19-37. https://doi.org/10.1007/978-0-230-37404-1_2

Gewati, Mikhael. (2019). "BI: Industri Pariwisati Jadi Sektor Paling Hasilkan Devisa", https://travel.kompas.com/read/2019/03/23/084500627/bi--industri-pariwisata-jadi-sektor-palinghasilkan-devisa (accessed on 06 April 2020) 
Institute For PR https://instituteforpr.org/crisis-management-and-communication/ (accessed on 20 May 2020)

Isa, N. F., Salleh, N. A. M., \& Aziz, A. A. (2016). Determinants and Impact of Online Social Interaction on Online Buying Behaviour. Procedia - Social and Behavioral Sciences, 219, 352-358. https://doi.org/10.1016/j.sbspro.2016.04.045

Kepmenparpostel.

1986. https://peraturan.bkpm.go.id/jdih/userfiles/batang/Kepmenparpostel_37_1986.pdf (accessed on 13 April 2020)

Labanauskaitè, D., Fiore, M., \& Stašys, R. (2020). Use of E-marketing tools as communication management in the tourism industry. Tourism Management Perspectives, 34(November 2019). https://doi.org/10.1016/j.tmp.2020.100652

Mihaela, O. O. E. (2015). The Influence of the Integrated Marketing Communication on the Consumer Buying Behaviour. Procedia Economics and Finance, 23(October 2014), 1446-1450. https://doi.org/10.1016/s2212-5671(15)00446-3

Prasetyo, D Bambang dkk. (2018). "Komunikasi Pemasaran Terpadu”. Malang: UB Press

Sudarso, Andriasan. (2016). "Manajemen Pemasaran Jasa perhotelan (Dilengkapi Dengan Hasil Riset Pada Hotel Berbintang di Sumatera Utara)". Sleman: deepublish

Shaluf, I. M., Ahmadun, F. R., \& Said, A. M. (2001). A review of disaster and crisis. Disaster Prevention and Management: An International Journal, 12(1), 24-32. https://doi.org/10.1108/09653560310463829

Wang, T \& Hsieh, H. (2016). Crisis Management in Tourism Industry. International Journal of Business Management \& Research (IJBMR), 6(5), 97-102. http://www.tjprc.org/view-archives.php

Widyastuti, S. (2017). Managemen Komunikasi Pemasaran Terpadu. 382. file:///C:/Users/Watashi/Downloads/pemasaran 3.pdf

Wishnutama. 2020. Melalui postingan di instagram. https://www.instagram.com/p/B-1TGcbAFI3/ (accessed on 12 April 2020)

World Health Organization. (2020). "Pertanyaan dan jawaban terkait Coronavirus", https://www.who.int/indonesia/news/novel-coronavirus/qa-for-public (accessed on 06 April 2020)

World Health Organization. 2020. "Updated WHO recommendations for international traffic in relation to COVID-19 outbreak", https://www.who.int/news-room/articles-detail/updated-whorecommendations-for-international-traffic-in-relation-to-covid-19-outbreak (accessed on 13 April)

Xliema, J. (2019). Effect of Social Networks o 11 Consumer Behaviour: Complex Buying. IFACPapersOnLine, 52(25), 504-508. https://doi.org/10.1016/j.ifacol.2019.12.594 


\title{
Perbedaan Kegiatan Komunikasi Pemasaran di Sheraton Surabaya Hotel \& Towers di Tengah Krisis Akibat Pandemi COVID-19
}

\begin{abstract}
Abstrak
Industri pariwisata merupakan industri yang berkembang sekaligus perhotelan sebagai penyedia akomodasi bagi wisatawan yang sedang melakukan kegiatan pariwisata. Namun pada tahun 2020 terjadi pandemi COVID-19 yang berdampak pada krisis di industri pariwisata. Penurunan jumlah wisatawan dan terbatasnya aktivitas pariwisata menyebabkan penurunan minat beli konsumen dan disini juga peran departemen komunikasi pemasaran sebagai departemen yang mempromosikan dan menjadi penghubung antara hotel dan konsumen. Peran komunikasi pemasaran dalam meningkatkan minat beli calon konsumen merupakan salah satu faktor yang berdampak karena adanya aktivitas departemen yang bertukar informasi dengan calon konsumen. Penelitian ini bertujuan untuk mengetahui kegiatan promosi dan adaptasi yang dilakukan oleh komunikasi pemasaran Sheraton Surabaya Hotel \& Towers dalam menghadapi krisis akibat pandemi COVID-19. Dalam penelitian ini peneliti menggunakan metode kualitatif yaitu data dianalisis terlebih dahulu kemudian disusun dan dijelaskan dengan pernyataan tertentu berupa kata-kata tertulis atau lisan dari seorang informan dan mengamati tempat yang diteliti. Hasil penelitian menunjukkan bahwa bagian komunikasi pemasaran Sheraton Surabaya Hotel \& Towers melakukan adaptasi terhadap manajemen krisis dan menggunakan soft selling dalam merencanakan langkah-langkah yang akan diambil setelah krisis berlalu. Kegiatan komunikasi pemasaran juga membantu untuk menjaga minat beli calon konsumen. Hasil penelitian juga menunjukkan bahwa penggunaan promosi melalui media sosial lebih fleksibel dalam berbagai kondisi.
\end{abstract}

Kata kunci: pariwisata, hotel, krisis, komunikasi pemasaran, minat beli, Covid-19 